\title{
The Influence of Purchase Date and Flight Duration over the Dispersion of Airline Ticket Prices
}

\author{
Tomasz Stanisław Szopiński ${ }^{1}$, Robert Nowacki ${ }^{1}$
}

\begin{abstract}
For many years, the air travel market has been the most regulated sector of the economy. Within the last few decades, it has undergone profound change, which is largely a consequence of changes in the law. Another factor that exerted influence on the market was the popularization of new information and communication technologies that affected the interaction between service providers and clients. Due to the application of modern technologies, it is easier for tradesmen to implement pricing policies to maximize profits or minimize losses. In turn, customers acquired a tool for comparing prices, which aids them in selecting the most advantageous offer from their point of view. This study aims to provide an answer to the following questions: how does flight duration affect the price dispersion of airline tickets and does price dispersion increase as the date of departure approaches. To answer these questions, airline ticket prices for flights on the route: Warsaw-London-Warsaw and the route: Warsaw-New York-Warsaw were observed between August 14 and November 14, 2014. Price dispersion increased on both routes as the date of departure approached. Analysis of price variation over time has revealed that longer flights (WAW-ZYP-WAW vs WAW-LHR-WAW) were less dispersed in terms of prices in the period under analysis.
\end{abstract}

KEY WORDS: $\quad$ airline ticket dispersion, air transport market, price comparison, pricing policy

JEL Classification: D120, F120, L81

1 University of Finance and Management, Warsaw, Poland

\section{Introduction}

The development of civilization in the contemporary world and the increased affluence of societies have led to changes in the operation of today's markets. New consumption trends are emerging and are related to the development of higher-order needs. Meeting these needs depends on modern technologies, including transport and communication technolo-

Correspondence concerning this article should be addressed to: Tomasz Stanisław Szopiński, University of Finance and Management, Pawia 55, 01-030 Warsaw, Poland. E-mail: tszopinski@wp.pl gies. As far as transport is concerned, the dynamic development of the air travel market has manifested itself through an increasing number of airlines, airports, flight routes as well as through the passengers using them. Air transport is a significant factor that has contributed to the development of many sectors of the economy, including global tourism (MartinConsuegra, Molina \& Esteban, 2006). For many years, it has been the most regulated sector of the economy (Button, 2009). As a result, the monopolistic position of many national carriers in the majority of countries contributed to the very high price of air 
travel and consequently - to a relatively low interest in it (Pijet-Migoń, 2012). The answer to this problem was the liberalization of the air travel market (Button, 2009; Grotte, 2013; Pijet-Migoń, 2012; Valdes, 2015). Along with the extension of the European Union, this specific revolution in passenger air transport has spread to new Member States in Central and Eastern Europe. Its most visible manifestation was the emergence of low-cost airlines in the Polish market (PijetMigoń, 2012). The development of the Internet is also a significant factor that has contributed to changes in the operation of the air travel market. It has revolutionized marketing communication and become the basic source of information for air services as well as a distribution channel for flight tickets.

The development of modern information and communication technologies, including the dynamic expansion of the Internet, has led to a change in business models and influenced interactions between market participants (Szopiński, 2012). Modern technologies have contributed to the gradual transformation in the manner business is conducted by exerting influence over the relationships of firms with suppliers, clients, production processes, other companies as well as over the manner of financing (Castells, 2003). The development of the Internet has also contributed to changes in the operation of the air travel market. It has revolutionized marketing communication and become the basic source of information for air services as well as a distribution channel for flight tickets. Unlike any other tool, the Internet offers abundant possibilities for information management. It is an effective tool that helps the development and operation of the modern economy and contributes to the emergence of new services, including information management services.

For example, some websites allow users to compare prices and select the parameters of goods or services, including both those offered via traditional channels and those sold via the Internet. The development of the Internet has changed the market for firms in many sectors, including the tourist and transport industries. Modern information and communication technologies have offered new marketing and management tools for tourism (Buhalis \& Law, 2008) and contributed to the emergence of many new types of services on the tourism market (Kabassi, 2010). The propensity to use travel websites to book tickets is the most visible among the youth, students, or educated people with high earnings, who often travel, have no problems with trip reservation, and often use low-cost airlines (Castillo-Manzano \& López-Valpuesta, 2010). According to Wang and Law (2007), the application of information and communication technologies helps save time which may later be used for additional activities outside home, such as recreational activities, which simultaneously promotes the propensity to travel.

Consumers' choice to use air travel is strongly influenced by flight ticket prices and the convenience of making online purchases. These factors may motivate making new purchases later (Bigne, et al., 2010). The price is particularly important in such a case. According to Elhaj (2012), the price is the most significant factor that determines whether reservations are made in a traditional or Internet-based manner. Magnini and Carande analyzed consumer behaviors when buying tourist services through various distribution channels. In contrast to consumers who used the telephone to buy hotel services and flight tickets, consumers who made purchases via the Internet took into account a larger number of possibilities, displayed less loyalty towards a brand, were more infrequent users; and saw a greater level of risk in the unavailability of a tourist service sought (2011). Paradoxically, these differences were caused by the abundance of information which the recipient had access to through the Internet and did not foster more rational decision-making. This is relevant for price comparison websites, among other things. In principle, such websites should contribute to the simplification of the decision-making process and the rationalization of purchase decisions by comparing many offers and supplying the potential buyer with detailed recommendations. Unfortunately, the effectiveness of such websites is currently limited. Consumers may not trust them because owners of such comparison websites receive sales commission for the services that they render. Furthermore, price comparison websites often provide no more than a fraction of the offers available on the market and thus do not present the whole range of possibilities. The reason for this is that price comparison websites aggregate data relating only to the suppliers with which they have agreements. Moreover, different search engines are based on distinct mechanisms for searching through offers available on the market. To be fully effective, compari- 

Internet Price Effect (IPE) provides an explanation for this fact: it may be because of the different characteristics of clients who buy through the Internet or through traditional travel agencies. For instance, it turned out that clients visiting traditional travel agencies were more often members of the Frequent Flyer Program and more often bought tickets which did not have additional fees in case of changes, e.g., the date of departure (Brunger, 2010). Bachis and Piga (2011) analyzed the price strategies of low-cost airlines. They found that different prices are offered by the same e-seller on the same website and at the same time for exactly the same product.

Airlines that possess a large number of loyal clients are reluctant to use middlemen such as online travel agencies (OTAs), e.g., Expedia or Travelocity. Some carriers, such as Southwest Airlines and Ryanair do not use OTAs because, among other things, they can control prices offered to loyal clients on their own websites (Koo, Mantin \& O'Connor, 2011). Various agents selling flight tickets online offer identical tickets at different prices (Lin, Chen \& Song, 2009). Sengupta and Wiggins (2012) claim that price dispersion is lower in the online market than offline.

The choice of offers may be affected by the airline's reputation. Consumers are willing to pay more for the better reputation of a corporation (Graham \& Bansal, 2007) or manner of ticket price presentation (Palmer \& Boissy, 2009). With respect to danger, the customer is not able to evaluate the safety of the services offered by the airlines and is thus eager to pay a higher price for using the services rendered by big carriers rather than smaller, regional ones (Squalli, 2005). A study conducted in Spain shows that the main predictors of airline ticket online purchase intention are, by degree of importance: habits, money saving, performance expectancy, and ease of using the offer (Escobar-Rodríguez \& Carvajal-Trujillo, 2013). According to Sam and Tahir (2009), service providers that wish to enhance their clients' purchase intentions should exercise empathy when rendering services and increase the trust that customers place in them.

Alderighi et al. (2012) discovered that competition among full-service carriers affected the price levels in the business and the leisure segments asymmetrically. An increase in competition exerted a greater influence on price reduction in the business class than in the tourist class. However, increased competition in the low-cost airline market reduced fees for business tourists and people travelling for pleasure to a similar extent.

Low-cost airlines have become a major player that offers transport services on domestic and international markets (Dobruszkes, 2013; Pijet-Migoń, 2012). They offer over 30 percent of seats in the European market (Dobruszkes, 2013). The existence of low-cost airlines in the market has led to an increase in the number of people travelling by air (Lian \& Denstadli, 2010; Pijet-Migoń, 2012).

Global distribution systems and travel agencies operating on the Internet have become a significant intermediary. Technological development, in turn, has facilitated price comparison for clients. Travel service providers have suffered losses because of that the ease of price comparison. To protect themselves against losses, providers try to vary offers by adding or removing certain components of a service (Granados et al., 2012a; Granados et al., 2012b). Isler and D'Souza (2009) argue that the reason for wide-spread implementation of global distribution systems is to allow airlines to practice price discrimination.

A characteristic feature of services rendered by airlines is the commoditization of offers. Airlines must attempt to vary their offers (Rothkopf \& Wald, 2011). Demand for flight tickets bought for business reasons is less elastic than the demand for tickets bought for tourist reasons (Brons, et al., 2002). People travelling for business are willing to pay a higher price for an airline ticket because they need to be able to change their travel plans (Brons, et al., 2002). Typically, the longer the journey, the smaller the price elasticity for clients buying airline tickets. This is because of the lack of substitute transport on long-distance routes (Brons, et al., 2002).

Studies on the relationships between the price dispersion of flight tickets and competition in air travel offer various conclusions. According to Borenstein and Rose, price dispersion is present on routes which have greater competition or a lower density of connections. On routes serviced by more than one carrier, mean price dispersion among companies is lower than the mean difference between prices paid by different clients for the same route to the same carrier. If the number of airlines increases and the total number of 



\section{Research results}

For flights on the WAW-LHR-WAW route, the mean price range was between PLN 762.30 (Air France) and PLN 1114.20 (SAS). The coefficients of variation estimated for each carrier strongly varied and ranged between 0.054 for Brussels Airlines and 0.265 for Alitalia (see Table 1). Two groups of carriers stood out. The first group was airlines with low price dispersion (coefficient of variation below 0.10 ). In addition to Brussels Airlines, this group included LOT, Lufthansa, Jat Airways, and Swiss Air. The second group included airlines that offered ticket prices that were changed considerably throughout the three-month period under analysis (coefficient of variation above 0.10): next to Alitalia, these were KLM, Air France, and SAS. The prices of the most expensive carrier (SAS) and the two cheapest ones - whose average price was the lowest among the airlines under analysis - (Air France and KLM) fluctuated frequently.

For the Warsaw - New York - New York route, the range of mean prices offered by the particular carriers was between PLN 2422.81 (Delta) and PLN 2115.90 (Airberlin). The range between the coefficients of variation was only 0.132 . Table 2 demonstrates that the lowest value observed was for the British Airways (0.026) and the highest was for KLM (0.158). Thus, a considerably smaller range of values of the coefficient of ticket price dispersion for each carrier is observable on the WAW-ZYP-WAW route in comparison to the WAWLHR-WAW route. Higher levels of the coefficient of dispersion were observable in cases of airlines that offered higher average prices, though this group included the cheapest carrier as well.

Much more characteristic correlations were revealed during the analysis of differences in prices over time. Table 3 presents changes in the price dispersion of airline tickets offered by airlines on the routes WAWLHR-WAW and WAW-ZYP-WAW between August 14 and November 14, 2014 for a flight on 15/11/2014 with a return date set for 22/11/2014. Analysis was concerned with mean prices published on a given day, which were calculated as an arithmetic mean of prices offered by each carrier. Throughout the three-month observation, the lowest mean price was PLN 789.43 and the lowest prices were offered more or less 30 days before departure. Table 3 shows that the flights on the route WAW-LHR-WAW were the most expensive on the day before departure - PLN 1193.60. Additionally, the coefficient of variation was the highest for that day -0.307 . Its smallest value -0.076 was recorded 24 days before departure. In analyzing the fluctuations in the values of this indicator, a long phase of relative stability that lasts until about the middle of the period under analysis is noticeable, i.e., till about the 30 th day before departure; then a phase of relatively large fluctuations lasting approximately the next 20 successive days, with a phase of definite increase in prices in the last ten days before departure. Time influences the range of fluctuations in prices.

Analysis of variation in prices over time showed that the more distant the flight, the less varied the price was (see Table 3 ). For the route WAW-ZYPWAW, the lowest value of the mean price of all the carriers on a given day was PLN 2047.30, and the highest - PLN 2675.67. Table 3 shows that the most attractive prices were offered about two months before departure, and the least attractive price was recorded on the tenth day before the flight. The coefficient of variation ranged between 0.023 and 0.142 . The lowest dispersion was recorded in the period in which low prices were offered (i.e., approximately 60 days before departure), the highest - about four weeks before the flight. Analysis of the trends of the coefficient of variation clearly expose a period of relative stability (the first six weeks under observation), a 20-day phase of gradual growth in prices, a 1-week period of decreasing prices, and a three-week period with a slight tendency for growth and singular occurrences of a downward trend.

Subsequently, linear regression was conducted, which was concerned with the dependency between the time remaining before departure and ticket prices offered by a given carrier on different days. Time was the factor which best accounted for changes in ticket prices on the route WAW-LHR-WAW in the case of Alitalia. Nearly $60 \%$ of changes in the prices offered by Alitalia were accounted for by a change in time (see Table 4). A change in time by one day translated into a change in price by PLN 9.90. The case was similar for the airlines such as KLM and Air France. For Air France, a change in time accounted for almost $50 \%$ of changes in prices. A change in time by one day translated into an almost $5 \%$ change in price. For KLM, a change in time accounted for ap- 
Table 1. Comparison of airline ticket price dispersion of the particular carriers on the WAW-LHR-WAW route

\begin{tabular}{lccccccccc}
\hline Stat. & LO & AF & KL & AZ & SN & LU & QJ & LX & SK \\
\hline Std. & 50.84 & 121.94 & 183.74 & 233.49 & 45.99 & 58.78 & 80.02 & 83.61 & 176.59 \\
Avg & 836.33 & 762.27 & 810.75 & 881.69 & 848.15 & 904.63 & 986.48 & 897.27 & 1114.18 \\
coeff. of var. & 0.061 & 0.160 & 0.227 & 0.265 & 0.054 & 0.065 & 0.081 & 0.093 & 0.158 \\
\hline
\end{tabular}

Table 2. Comparison of airline ticket price dispersion of the particular carriers on the WAW-ZYP-WAW route

\begin{tabular}{lcccccccccc}
\hline Stat. & KL & AB & AF & DL & LH & AA & BA & LX & OS & UA \\
\hline Std. & 371.81 & 287.84 & 170.59 & 291.05 & 229.01 & 72.37 & 58.26 & 284.93 & 310.09 & 185.75 \\
Avg & 2355.50 & 2115.90 & 2207.69 & 2422.81 & 2263.51 & 2186.94 & 2204.26 & 2394.81 & 2363.92 & 2211.79 \\
coeff. of var. & 0.158 & 0.136 & 0.077 & 0.120 & 0.101 & 0.033 & 0.026 & 0.119 & 0.131 & 0.084 \\
\hline
\end{tabular}

proximately $45 \%$ of changes in prices. A change in the day of purchase of a ticket by one day translated into a change in the price by nearly PLN 7. The regression model accounted for the dependency between time and changes in prices offered by Brussels Airlines the least. Time accounted for only approximately $7 \%$ of changes. The case was similar for Lufthansa. Time accounted for only $9 \%$ of changes.

Analysis of linear regression describing the influence of a change in time over changes in prices offered by 10 carriers for flight tickets on the route WAWZYP-WAW demonstrated that time accounted for over $40 \%$ of changes in price for airlines such as KLM, Air France, Delta, Lufthansa, and Swiss and Austrian (see Table 5). For American Airlines and British Airlines time accounted for over $10 \%$ of changes in prices. Only one of the ten airlines under analysis (United Airlines) had no statistically significant correlation between the date of ticket purchase and its price.

Comparing both connections - to London and to New York - a much higher level of stability in ticket prices is evident in the case of the latter. Dispersion measured with the coefficient of variation is considerably smaller for flights on the route WAW-ZYP-WAW than WAW-LHR-WAW. Examination of dispersion within the time frame of the study revealed that the average value of the coefficient of variation in prices for the flights on the route WAW-ZYP-WAW was 0.077 , while it was twice as much for the flights to London 0.158 . The range of fluctuations was characterized by similar relationships -0.119 for New York and 0.231 for London.

Examination of the correlation between the number of days before departure and the mean flight ticket prices offered by various carriers on the route WAW-LHR-WAW revealed that the correlation was two-tailed, significant at the level of 0.01 , and negative (the Pearson's coefficient: minus 0.554), which signified that the price of the flight visibly increased as the number of days before the departure decreased. Linear regression showed that if the time before departure was shortened by one day, the average price changed by PLN 2.25. In the case of flights on the route WAW-LHR-WAW, time accounted for almost $30 \%$ of variation in mean prices. However, if we look at the data in table 6 , there is no significant correlation between the number of days remaining before the flight and the coefficient of variation in price. The correlation measured with the Pearson's coefficient was merely minus 0.238 and was not statistically sig- 
Table 3. Comparison of airline ticket price dispersion on the WAW-LHR-WAW and WAW-ZYP-WAW routes offered between August 14 and November 11, 2014 for the flight on 11/15/2014.

\begin{tabular}{|c|c|c|c|c|c|c|c|}
\hline \multirow[b]{2}{*}{ No. } & \multirow[b]{2}{*}{$\begin{array}{c}\text { date of } \\
\text { observation }\end{array}$} & \multicolumn{3}{|c|}{ WAW-LHR-WAW } & \multicolumn{3}{|c|}{ WAW-ZYP-WAW } \\
\hline & & Std & Avg & $\begin{array}{c}\text { Price } \\
\text { dispersion } \\
\text { coefficient }\end{array}$ & Std & Avg & $\begin{array}{c}\text { Price } \\
\text { dispersion } \\
\text { coefficient }\end{array}$ \\
\hline 1. & $8 / 14 / 2014$ & 134.28 & 882.13 & 0.152 & 89.52 & 2155.90 & 0.042 \\
\hline 2. & $8 / 15 / 2014$ & 134.28 & 882.13 & 0.152 & 89.41 & 2149.10 & 0.042 \\
\hline 3. & $8 / 16 / 2014$ & 134.28 & 882.13 & 0.152 & 89.41 & 2149.10 & 0.042 \\
\hline 4. & $8 / 17 / 2014$ & 134.28 & 882.13 & 0.152 & 89.41 & 2149.10 & 0.042 \\
\hline 5. & $8 / 18 / 2014$ & 124.97 & 839.29 & 0.149 & 89.41 & 2149.10 & 0.042 \\
\hline 6. & $8 / 19 / 2014$ & 142.30 & 833.89 & 0.171 & 83.90 & 2163.90 & 0.039 \\
\hline 7. & $8 / 20 / 2014$ & 141.40 & 833.00 & 0.170 & 87.23 & 2163.50 & 0.040 \\
\hline 8. & $8 / 27 / 2014$ & 134.37 & 848.71 & 0.158 & 82.98 & 2208.33 & 0.038 \\
\hline 9. & $8 / 28 / 2014$ & 136.45 & 856.25 & 0.159 & 88.18 & 2235.56 & 0.039 \\
\hline 10. & $8 / 30 / 2014$ & 147.17 & 897.00 & 0.164 & 92.55 & 2175.89 & 0.043 \\
\hline 11. & $8 / 31 / 2014$ & 134.34 & 853.29 & 0.157 & 76.97 & 2143.40 & 0.036 \\
\hline 12. & 9/1/2014 & 126.18 & 856.50 & 0.147 & 79.93 & 2138.44 & 0.037 \\
\hline 13. & $9 / 8 / 2014$ & 159.34 & 886.63 & 0.180 & 90.13 & 2093.40 & 0.043 \\
\hline 14. & $9 / 15 / 2014$ & 119.58 & 843.78 & 0.142 & 107.10 & 2068.56 & 0.052 \\
\hline 15. & $9 / 16 / 2014$ & 120.42 & 855.00 & 0.141 & 118.14 & 2096.80 & 0.056 \\
\hline 16. & $9 / 17 / 2014$ & 122.88 & 872.75 & 0.141 & 116.22 & 2092.56 & 0.056 \\
\hline 17. & $9 / 18 / 2014$ & 116.26 & 857.22 & 0.136 & 110.67 & 2092.70 & 0.053 \\
\hline 18. & 9/19/2014 & 149.82 & 884.78 & 0.169 & 82.52 & 2057.10 & 0.040 \\
\hline 19. & $9 / 21 / 2014$ & 155.25 & 905.00 & 0.172 & 57.01 & 2074.60 & 0.027 \\
\hline 20. & $9 / 22 / 2014$ & 148.65 & 884.00 & 0.168 & 48.08 & 2049.30 & 0.023 \\
\hline 21. & $9 / 23 / 2014$ & 149.96 & 885.78 & 0.169 & 51.85 & 2057.80 & 0.025 \\
\hline 22. & $9 / 24 / 2014$ & 146.29 & 864.56 & 0.169 & 51.68 & 2054.40 & 0.025 \\
\hline 23. & $9 / 25 / 2014$ & 153.39 & 883.25 & 0.174 & 51.13 & 2047.30 & 0.025 \\
\hline 24. & $9 / 26 / 2014$ & 110.71 & 841.57 & 0.132 & 95.40 & 2118.40 & 0.045 \\
\hline 25. & $9 / 28 / 2014$ & 115.47 & 860.43 & 0.134 & 49.95 & 2049.30 & 0.024 \\
\hline 26. & 9/29/2014 & 119.52 & 863.86 & 0.138 & 132.59 & 2135.78 & 0.062 \\
\hline 27. & 9/30/2014 & 135.98 & 858.57 & 0.158 & 88.66 & 2099.00 & 0.042 \\
\hline 28. & $10 / 1 / 2014$ & 116.93 & 833.38 & 0.140 & 106.27 & 2134.67 & 0.050 \\
\hline 29. & $10 / 2 / 2014$ & 153.49 & 860.67 & 0.178 & 129.98 & 2248.33 & 0.058 \\
\hline
\end{tabular}


Table 3. Comparison of airline ticket price dispersion on the WAW-LHR-WAW and WAW-ZYP-WAW routes offered between August 14 and November 11, 2014 for the flight on 11/15/2014. (Continued)

\begin{tabular}{|c|c|c|c|c|c|c|c|}
\hline \multirow[b]{2}{*}{ No. } & \multirow[b]{2}{*}{$\begin{array}{c}\text { date of } \\
\text { observation }\end{array}$} & \multicolumn{3}{|c|}{ WAW-LHR-WAW } & \multicolumn{3}{|c|}{ WAW-ZYP-WAW } \\
\hline & & Std & Avg & $\begin{array}{c}\text { Price } \\
\text { dispersion } \\
\text { coefficient }\end{array}$ & Std & Avg & $\begin{array}{c}\text { Price } \\
\text { dispersion } \\
\text { coefficient }\end{array}$ \\
\hline 30. & $10 / 6 / 2014$ & 132.79 & 853.14 & 0.156 & 131.88 & 2198.80 & 0.060 \\
\hline 31. & 10/8/2014 & 121.19 & 865.43 & 0.140 & 163.68 & 2258.11 & 0.072 \\
\hline 32. & 10/10/2014 & 92.01 & 804.50 & 0.114 & 213.86 & 2193.33 & 0.098 \\
\hline 33. & 10/11/2014 & 97.73 & 809.50 & 0.121 & 262.03 & 2250.38 & 0.116 \\
\hline 34. & 10/15/2014 & 91.72 & 797.88 & 0.115 & 257.31 & 2267.44 & 0.113 \\
\hline 35. & 10/16/2014 & 94.25 & 803.63 & 0.117 & 265.30 & 2272.67 & 0.117 \\
\hline 36. & $10 / 17 / 2014$ & 189.55 & 855.00 & 0.222 & 283.48 & 2269.33 & 0.125 \\
\hline 37. & $10 / 18 / 2014$ & 94.40 & 801.29 & 0.118 & 322.64 & 2264.67 & 0.142 \\
\hline 38. & 10/19/2014 & 171.44 & 910.88 & 0.188 & 292.86 & 2277.44 & 0.129 \\
\hline 39. & $10 / 20 / 2014$ & 94.40 & 801.29 & 0.118 & 263.94 & 2243.56 & 0.118 \\
\hline 40. & $10 / 21 / 2014$ & 69.05 & 789.43 & 0.087 & 263.75 & 2276.44 & 0.116 \\
\hline 41. & $10 / 22 / 2014$ & 62.13 & 818.57 & 0.076 & 323.08 & 2369.56 & 0.136 \\
\hline 42. & $10 / 23 / 2014$ & 111.86 & 854.78 & 0.131 & 291.64 & 2325.11 & 0.125 \\
\hline 43. & $10 / 24 / 2014$ & 86.42 & 838.00 & 0.103 & 251.38 & 2256.11 & 0.111 \\
\hline 44. & $10 / 25 / 2014$ & 82.30 & 825.25 & 0.100 & 260.71 & 2285.22 & 0.114 \\
\hline 45. & $10 / 26 / 2014$ & 82.30 & 825.25 & 0.100 & 201.75 & 2439.89 & 0.083 \\
\hline 46. & $10 / 27 / 2014$ & 106.85 & 869.11 & 0.123 & 201.24 & 2423.22 & 0.083 \\
\hline 47. & $10 / 28 / 2014$ & 167.22 & 904.88 & 0.185 & 176.76 & 2386.56 & 0.074 \\
\hline 48. & 10/30/2014 & 239.04 & 965.50 & 0.248 & 205.84 & 2473.89 & 0.083 \\
\hline 49. & 10/31/2014 & 164.64 & 903.38 & 0.182 & 209.86 & 2441.22 & 0.086 \\
\hline 50. & $11 / 1 / 2014$ & 199.38 & 914.13 & 0.218 & 251.30 & 2486.33 & 0.101 \\
\hline 51. & $11 / 2 / 2014$ & 152.61 & 918.00 & 0.166 & 246.29 & 2443.22 & 0.101 \\
\hline 52. & $11 / 3 / 2014$ & 199.04 & 931.25 & 0.214 & 250.41 & 2526.22 & 0.099 \\
\hline 53. & $11 / 4 / 2014$ & 95.97 & 911.00 & 0.105 & 327.19 & 2675.67 & 0.122 \\
\hline 54. & $11 / 5 / 2014$ & 100.62 & 904.00 & 0.111 & 259.07 & 2574.11 & 0.101 \\
\hline 55. & $11 / 6 / 2014$ & 126.31 & 920.00 & 0.137 & 348.00 & 2611.22 & 0.133 \\
\hline 56. & $11 / 7 / 2014$ & 165.62 & 1033.29 & 0.160 & 291.33 & 2611.67 & 0.112 \\
\hline 57. & $11 / 8 / 2014$ & 195.65 & 970.50 & 0.202 & 351.55 & 2535.00 & 0.139 \\
\hline 58. & $11 / 9 / 2014$ & 195.65 & 970.50 & 0.202 & 213.97 & 2447.33 & 0.087 \\
\hline
\end{tabular}


Table 3. Comparison of airline ticket price dispersion on the WAW-LHR-WAW and WAW-ZYP-WAW routes offered between August 14 and November 11, 2014 for the flight on 11/15/2014. (Continued)

\begin{tabular}{|c|c|c|c|c|c|c|c|}
\hline \multirow[b]{2}{*}{ No. } & \multirow[b]{2}{*}{$\begin{array}{c}\text { date of } \\
\text { observation }\end{array}$} & \multicolumn{3}{|c|}{ WAW-LHR-WAW } & \multicolumn{3}{|c|}{ WAW-ZYP-WAW } \\
\hline & & Std & Avg & $\begin{array}{c}\text { Price } \\
\text { dispersion } \\
\text { coefficient }\end{array}$ & Std & Avg & $\begin{array}{c}\text { Price } \\
\text { dispersion } \\
\text { coefficient }\end{array}$ \\
\hline 59. & $11 / 10 / 2014$ & 204.50 & 980.50 & 0.209 & 340.31 & 2486.56 & 0.137 \\
\hline 60. & $11 / 11 / 2014$ & 197.28 & 1005.38 & 0.196 & 253.95 & 2522.00 & 0.101 \\
\hline 61. & $11 / 12 / 2014$ & 244.24 & 1070.38 & 0.228 & 271.38 & 2559.89 & 0.106 \\
\hline 62. & $11 / 13 / 2014$ & 254.93 & 1106.13 & 0.230 & 328.09 & 2583.67 & 0.127 \\
\hline 63. & $11 / 14 / 2014$ & 366.59 & 1193.63 & 0.307 & 310.26 & 2585.67 & 0.120 \\
\hline
\end{tabular}

Table 4. The results of linear regression between time remaining before departure and the prices of tickets on the WAWLHR-WAW route offered between 14 August, 2014 and 14 November.

\begin{tabular}{lccccccccc}
\hline $\begin{array}{l}\text { Airline } \\
\text { codes }\end{array}$ & LO & AF & KL & AZ & SN & LH & QJ & LX & SK \\
\hline $\begin{array}{l}\text { Beta/r } \\
\text { b (regression }\end{array}$ & $-0.472^{* *}$ & $-0.712^{* *}$ & $-0.681^{* *}$ & $-0.771^{* *}$ & $0.286^{*}$ & $0.323^{* *}$ & $-0.395^{* *}$ & $0.636^{* *}$ & $-0.430^{* *}$ \\
coefficient) & $-1.314^{* *}$ & $-4.741^{* *}$ & $-6.835^{* *}$ & $-9.903^{* *}$ & $0.728^{*}$ & $1.036^{* *}$ & $-1.742^{* *}$ & $2.814^{* *}$ & $-4.259^{* *}$ \\
Const. & $870.71^{* *}$ & $913.75^{* *}$ & $1029.22^{* *}$ & $1210.41^{* *}$ & $825.72^{*}$ & $871.25^{* *}$ & $1043.17^{* *}$ & $805.38^{* *}$ & $1273.36^{* *}$ \\
$R^{2}$-adjusted & 0.20 & 0.499 & 0.455 & 0.587 & 0.066 & 0.09 & 0.142 & 0.395 & 0.162 \\
F & $9.757^{* *}$ & $62.674^{* *}$ & $52.859^{* *}$ & $81.987^{* *}$ & $5.071^{*}$ & $7.109^{* *}$ & $10.906^{* *}$ & $39.463^{* *}$ & $8.37^{* *}$ \\
df & 34 & 61 & 61 & 56 & 57 & 61 & 59 & 58 & 37 \\
\hline
\end{tabular}

Note: ${ }^{*}$ Correlation significant at the level of 0.01

** Correlation significant at the level of 0.05

nificant. For flights on the route WAW-ZYP-WAW, there was a strong correlation between the date of departure and the average price level. It was -0.864 and statistically significant. Regression function showed that if the time before departure was shortened by one day, the average price increased by nearly PLN 8.5. For flights on the route WAW-ZYP-WAW, time accounted for almost $75 \%$ of variation in the mean price. Moreover, a statistically significant cor- relation was found between time and the coefficient of variation in price. Linear regression showed that if time before departure was shortened by one day, the price changed by $0.165 \%$ of the average price. For flights on the WAW-ZYP-WAW route, time accounted for $63 \%$ of variability in the coefficient of variation. For flights on the WAW-ZYP-WAW route, time better accounted for changes in the mean price than it did for flights on the route WAW-LHR-WAW. 
Table 5. Juxtaposition of correlations between the number of days before departure and prices of tickets offered by each carrier on the route WAW-ZYP-WAW

\begin{tabular}{lcccccccccc}
\hline $\begin{array}{l}\text { Airline } \\
\text { codes }\end{array}$ & $\mathbf{K L}$ & $\mathbf{A B}$ & $\mathbf{A F}$ & $\mathbf{D L}$ & $\mathbf{L H}$ & $\mathbf{A A}$ & $\mathbf{B A}$ & $\mathbf{L X}$ & OS & UA \\
\hline $\begin{array}{l}\text { Beta/r } \\
\text { b }\end{array}$ & $-0.886^{* *}$ & $-0.571^{* *}$ & $-0.719^{* *}$ & $-0.842^{* *}$ & $-0.655^{* *}$ & $-0.372^{* *}$ & $-0.415^{* *}$ & $-0.713^{* *}$ & $-0.741^{* *}$ & -0.259 \\
$\begin{array}{l}\text { (regression } \\
\text { coeff.) }\end{array}$ & $-16.331^{* *}$ & $-8.968^{* *}$ & $-6.641^{* *}$ & $-13.139^{* *}$ & $-8.170^{* *}$ & $-1.467^{* *}$ & $-1.311^{* *}$ & $-11.080^{* *}$ & $-12.535^{* *}$ & 3.142 \\
$\begin{array}{l}\text { Const. } \\
\text { R }\end{array}$ & $2914.16^{* *}$ & $2402.89^{* *}$ & $2420.31^{* *}$ & $2840.59^{* *}$ & $2530.20^{* *}$ & 2230.890 & $2246.02^{* *}$ & $2740.61^{* *}$ & $2765.044^{* *}$ & $2329.31^{* *}$ \\
adjusted & 0.781 & 0.315 & 0.509 & 0.704 & 0.420 & 0.124 & 0.158 & 0.499 & 0.542 & 0.049 \\
F & $168.766^{* *}$ & $29.529^{* *}$ & $64.361^{* *}$ & $138.623^{* *}$ & $42.924^{* *}$ & $9.777^{* *}$ & $12.288^{* *}$ & $56.840^{* *}$ & 74.272 & 3.607 \\
df & 46 & 61 & 60 & 57 & 57 & 61 & 59 & 55 & 61 & 50 \\
\hline
\end{tabular}

Note: **Correlation significant at the level of 0.05

Table 6. The results of linear regression between time remaining before departure and the average price of tickets offered on a given day by different airlines, and the time remaining before departure and the coefficient of variation for the flights for November 15, 2014.

\begin{tabular}{lcccc}
\hline & \multicolumn{2}{c}{ WAW-LHR-WAW } & \multicolumn{2}{c}{ WAW-ZYP-WAW } \\
\hline Statistics & Avg. & coeff. of var. & Avg. & coeff. of var. \\
\hline Beta/r & $-0.554^{* *}$ & -0.238 & $-0.864^{* *}$ & $-0.799^{* *}$ \\
b (regression coeff.) & $-2.250^{* *}$ & -0.001 & $-8.476^{* *}$ & $-0.00165^{* *}$ \\
Const. & $975.16^{* *}$ & $0.175^{* *}$ & $2546.98^{* *}$ & $0.130^{* *}$ \\
R $^{2}$ - adjusted & 0.296 & 0.041 & 0.743 & 0.633 \\
F & $27.015^{* *}$ & 3.669 & $179.798^{* *}$ & $107.863^{* *}$ \\
df & 63 & 63 & 63 & 63 \\
\hline
\end{tabular}

Note: ${ }^{* *}$ Correlation significant at the level of 0.05

\section{Conclusions and recommendations}

The analysis in this paper demonstrates that as the date of departure approaches, price dispersion of airline tickets offered by various airlines on the routes WAWLHR-WAW and WAW-ZYP-WAW increases. Analysis of price variability over time demonstrates that more distant flights show less variation. In comparing both connections - to London and to New York, a much higher level of stability in ticket prices is evident on the Warsaw-New York-Warsaw route. Price dispersion measured with the coefficient of variation is much smaller for ticket prices on the Warsaw-New York-Warsaw route than for the Warsaw-London-Warsaw route.

Research on marketing strategies in the passenger air transport market in Europe is lacking. Studies that examine the American and Asian markets dominate. The European market is different. One example is dissimilar productivity. Analysis of the results generated 
in the European and American markets from 20012008 revealed that European airlines were more effective. Additionally, in terms of productivity growth, European airlines perform slightly better in most years (Assaf \& Josiassen, 2012).

Flights on only two routes were analyzed. More in-depth analysis is needed to verify whether tickets offered for longer routes are actually characterized by lower price dispersion. The factor that hinders analysis of airline ticket prices offered on given routes by various carriers is the lack of knowledge about the conditions underlying cooperation between a price comparison website and each carrier. The amount and manner of calculation of the commission may occasionally influence the manner of presentation of the results to the consumers' queries about specific flights.

It would be interesting to carry out research investigating the dispersion of airline ticket prices in different seasons of the year based on a fixed period between the date of registration of a price and the date of departure. Another interesting issue is the price dispersion of airline ticket prices on the following routes: Warsaw Chopin Airport (WAW)-London and Warsaw Modlin Airport (WMA)-London. There is competition between the Warsaw Chopin Airport and the recently opened Warsaw Modlin Airport, which is trying to attract carriers, often at the expense of the Warsaw Chopin Airport.

\section{References}

Alderighi, M., Cento, A. \& Piga, C. A. (2011). A case study of pricing strategies in European airline markets: The London - Amsterdam route. Journal of Air Transport Management, 17 (6), 369-373.

Alderighi, M., Cento, A., Nijkamp, P., Rietveld, P. (2012). Competition in the European aviation market: the entry of low-cost airlines. Journal of Transport Geography, 24, 223-233.

Assaf, A. G., Josiassen, A. (2012). European vs. U.S. airlines: Performance comparison in a dynamic market. Tourism Management, 33 (2), 317-326.

Bachis, E., Piga, C. A. (2011). Low-cost airlines and online price dispersion. International Journal of Industrial Organization, 29 (6), 655-667.

Bigné, E., Hernández, B., Ruiz, C. \& Andreu, L. (2010). How motivation, opportunity and ability can drive online airline ticket purchases. Journal of Air Transport Management, 16 (6), 346-349.
Bilotkach, V., Gorodnichenko, Y., \& Talavera, O. (2010). Are airlines' price-setting strategies different? Journal of Air Transport Management, 16 (1), 1-6.

Borenstein, S. \& Rose, N. (1994). Competition and Price Dispersion in the U.S. Airline Industry. Journal of Political Economy, 102 (4), 653-683.

Brons, M., Pels, E., Nijkamp, P. \& Rietveld, P. (2002). Price elasticities of demand for passenger air travel: a meta-analysis. Journal of Air Transport Management, 8(3), 165-175.

Brunger, W. G. \& Perelli, S. (2009). The impact of the internet on airline fares: Customer perspectives on the transition to internet distribution. Journal of Revenue \& Pricing Management, 8 (2-3), 187-199.

Brunger, W. G. (2010). The impact of the Internet on airline fares: The 'Internet Price Effect'. Journal of Revenue \& Pricing Management, 9 (1-2), 66-93.

Brynjolfsson, E., Dick, A. \& Smith, M. (2010). A nearly perfect market? Quantitative Marketing \& Economics, 8 (1), 1-33.

Buhalis, D., Law. R. (2008). Progress in information technology and tourism management: 20 years on and 10 years after the Internet. Tourism Management, 29 (4), 609-623.

Button, K. (2009). The impact of US-EU “Open Skies" agreement on airline market structures and airline networks. Journal of Air Transport Management, 15, 59-71.

Castillo-Manzano, J. I., López-Valpuesta, L. (2010). The decline of the traditional travel agent model. Transportation Research, 46 (5), 639-649.

Castells, M. (2003). Galaktyka Internetu. Refleksje nad Internetem, Biznesem i Społeczeństwem [The Internet Galaxy: Reflections on the Internet, Business and Society]. Poznań: Dom Wydawniczy Rebis.

Chakrabarty, D., Kutlu, L. (2014). Competition and price dispersion in the airline markets. Applied Economics, 46 (28), 3421-3436.

Chellappa, R. K., Sin, R. G. \& Siddarth, S. (2011). Price Formats as a Source of Price Dispersion: A Study of Online and Offline Prices in the Domestic U.S. Airline Markets. Information Systems Research, 22 (1), 83-98.

Dai, M., Liu, Q., Serfes, K. (2014). Is the effect of competition on price dispersion non-monotonic? Evidence from the U.S. airline industry. The Review of Economics and Statistics, 96 (1), 161-170. 
Dobruszkes, F. (2013). The geography of European low-cost airline networks: a contemporary analysis. Journal of Transport Geography, 28, 2875-2888.

Domínguez-Menchero, J. S., Rivera, J., Torres-Manzanera, E. (2014). Optimal purchase timing in the airline market. Journal of Air Transport Management, 40, 137-143.

Elhaj, M. (2012). Factors that contribute to consumers' perceptions of online and traditional travel reservation systems. Anatolia: An International Journal Of Tourism \& Hospitality Research, 23 (1), 118-122.

Escobar-Rodríguez, T., Carvajal-Trujillo, E. (2013). Online drivers of consumer purchase of website airline tickets. Journal of Air Transport Management, 58-64.

Gaggero, A. A. \& Piga, C. A. (2011). Airline Market Power and Intertemporal Price Dispersion. The Journal of Industrial Economics, 59 (4), 552-577.

Gamper, H. (2012). How Can Internet Comparison Sites Work Optimally for Consumers? Journal of Consumer Policy, 35 (3), 333-353.

Gerardi, K. S. \& Shapiro, A. (2009). Does Competition Reduce Price Dispersion? New Evidence from the Airline Industry. Journal of Political Economy, 117 (1), 1-37.

Graham, M. \& Bansal, P. (2007). Consumers' Willingness to Pay for Corporate Reputation: The Context of Airline Companies. Corporate Reputation Review, 10 (3), 189-200.

Granados, N. F., Kauffman, R. J., Lai, H. \& Lin, H. (2012a). Decommoditization, Resonance Marketing, and Information Technology: An Empirical Study of Air Travel Services amid Channel Conflict. Journal of Management Information Systems, 28 (2), 39-74.

Granados, N., Kauffman, R. J., Lai, H. \& Lin, H. (2012b). À la Carte Pricing and Price Elasticity of Demand in Air Travel. Decision Support System, 53 (2), 381-394.

Grotte, J. (2013). Budget Tourism - Transition Economy. International Journal of Business Insights \& Transformation, 6 (2), 104-109.

Grover, V., Lim, J. \& Ayyagari, R. (2006). The Dark Side of Information and Market Efficiency in E-Markets. Decision Sciences, 37 (3), 297-324.

Isler, K. \& D'Souza, E. (2009). GDS capabilities, OD control and dynamic pricing. Journal of Revenue \& Pricing Management, 8 (2-3), 255-266.
Kabassi, K. (2010). Personalizing recommendations for tourists. Telematics and Informatics, 27 (1), $51-66$.

Koo, B., Mantin, B. \& O’Connor, P. (2011). Online distribution of airline tickets: Should airlines adopt a single or a multi-channel approach? Tourism Management, 32 (1), 69-74.

Lian, J. \& Denstadli, J. (2010). Booming Leisure Air Travel to Norway - The Role of Airline Competition. Scandinavian Journal of Hospitality \& Tourism, 10 (1), 1-15.

Lin, P., Chen, C. \& Song, M. (2009). Price dispersion of online air tickets for short distance international routes. Service Industries Journal, 29 (11), 1597 1613.

Lott, J. R. \& Roberts, R. D. (1991). A Guide to the Pitfalls of Identifying Price. Discrimination. Economic Inquiry, 29 (1), 14-23.

Magnini, V. P. \& Karande, K. (2011). Understanding consumer services buyers based upon their purchase channel. Journal of Business Research, 64 (6), 543-550

Mantin, B. \& Koo, B. (2010). Weekend effect in airfare pricing. Journal of Air Transport Management, 16 (1), 48-50.

Martin-Consuegra, D., Molina A. \& Esteban, Á. (2006). Customer Orientation in the Airline Industry: A Comparison between Travelers and Airlines. e-Review of Tourism Research, 4 (5), 108-118.

Nelson, R. A., Cohen, R. \& Rasmussen, F. (2007). An Analysis of Pricing Strategy and Price Dispersion on the Internet. Eastern Economic Journal, 33 (1), 95-110.

Narangajavana, Y, Garrigos-Simon, F. J., Sanches-Garcia, J. (2014). Prices, prices and prices: A Study in the Passenger Airline Industry. Tourism Management, 41, 28-42.

Obermeyer, A., Evangelinos, C. \& Püschel, R. (2013). Price dispersion and competition in European airline markets. Journal of Air Transport Management, 26, 31-34.

Palmer, A. \& Boissy, S. (2009). The effects of airline price presentations on buyers' choice. Journal of Vacation Marketing, 15 (1), 39-52.

Petrescu, M. (2011). Online price dispersion - more than imperfect information. Journal Of Product \& Brand Management, 20 (7), 541-548. 
Pijet-Migoń, E. (2012). Zmiany rynku lotniczych przewozów pasażerskich $w$ Polsce po akcesji do Unii Europejskiej [Changes on the Market of Air Travel in Poland after Accession to the European Union]. Rozprawy Naukowe Instytutu Geografii i Rozwoju Regionalnego 25. Wrocław: Uniwersytet Wrocławski.

Roma, P., Zambuto, F., Perrone, G. (2014). Price dispersion, competition, and the role of online travel agents: Evidence from business routes in the Italian airline market. Transportation Research, 69, 146-159.

Rothkopf, M. \& Wald, A. (2011). Innovation in Commoditized Services: A Study In The Passenger Airline Industry. International Journal Of Innovation Management, 15 (4), 731-753.

Sam, M. F. M. \& Tahir, M. N. H. (2009). Website Quality and Consumer Online Purchase Intention of Air Ticket. International Journal of Basic \& Applied Sciences, 9 (10), 4-9.

Sengupta, A. \& Wiggins, S. N. (2012). Comparing Price Dispersion on and off the Internet Using Airline Transaction Data. Review of Network Economics, 11 (1), DOI: 10.1515/1446-9022.1244.

Stavins, J. (2001). Price Discrimination in the Airline Market: The Effect of Market Concentration. Review of Economics \& Statistics, 83 (1), 200-202.

Squalli, J. (2005). Optimal fares under uncertainty about airline safety. Applied Economics Letters, 12 (4), 223-226.

Szopiński, T. (2012). E-konsument na rynku usług [Econsumer on the Market for Services]. Warszawa: CeDeWu.

Szopiński, T. \& Nowacki, R. (2014). Plane Ticket Price Dispersion in the Online Selling System in Poland. Contemporary Economics, 8 (2), 207-217.

Valdes, V. (2015). Determinants of air travel demand in Middle Income Countries. Journal of Air Transport Management, 42, 75-84.

Wang, D., \& Law, F. Y. T. (2007). Impacts of Information and Communication Technologies (ICT) on time use and travel behavior: a structural equations analysis. Transportation, 34 (4), 513-527.

Wang, S. W. (2014). Do global airline alliances influence the passenger's purchase decision? Journal of Air Transport Management, 37, 53-59. 